\title{
THE EFFECT OF WORD MAP STRATEGY USING INSTAGRAM TO DEVELOP STUDENTS' VOCABULARY
}

\author{
Nurul Qisthi \\ Universitas Muhammadiyah Gresik, East Java, Indonesia \\ mizqy@yahoo.com
}

Received: Agust 10, 2020

Accepted: Agust 17,2020

Published: August 9,2020

\begin{abstract}
:
Doi : http://dx.doi.org/10.30587/jetlal.v4i2.2273

Study on the use of Instagram has bloomed in EFL teaching learning process. Instagram is one of the favorite SNSs among students. This research aims to discover the effect using Instgram combined with Word Map strategy as learning tool in developing students' vocabulary by involving 64 Islamic junior high school students. They were asked to do vocabulary level test to measure their mastery in vocabulary. In supporting the data, a questionnaire was also distributed to the treatment group. A quasi-experimental design was employed during the study. A two-way ANOVA was used to analyze the data. The findings revealed that applying Word Map strategy with Instagram significantly improved students' vocabulary from $11 \%$ for the control group to $18.98 \%$ for the treatment group. Hence, developing Word Map strategy with mobile application integration to improve students' writing skill within EFL curriculum is worth investigating.
\end{abstract}

Keywords: ESP, Reading Comprehension, Online Students Response Systems Platforms.

\section{INTRODUCTION}

Generally, teaching vocabulary in English as a foreign language does not become primary thing and tend to be ignored in classroom activity. Teachers teach vocabulary by memorizing, repeating, translating and finding the difficult words by dictionary (Alizadeh, 2016). Teachers do those kind of strategies because they are easy to apply in class and do not need a lot of preparation. On the previous study, Ahour and Berenji (2015) applied repetition and recalling of words using Iranian learners and found that the result was good but in short term memory. Teachers tend to teach vocabulary without giving opportunity to the learners to think analytically and critically because teaching vocabulary becomes second focus for the teachers in teaching English. The teaching and learning process is directly directed only on the word to be learned without relating to the context (Schmitt, 2000). Therefore, thinking both critically and analytically are needed so that the learners can have proper learning and chance to have great experience in learning English as foreign language by letting the students to observe, discuss, and analyze the words given.

To overcome such a problem, there are many techniques and methods can be applied in teaching vocabulary to English foreign learners. The techniques and methods are applied to the students to comprehend, analyze and use the information both in individual or group (Kafadar, 2013). According to O'Malley and Chamot in 1995 mentioned that the techniques should provide the cognitive aspect combined with social affective experience. Supporting that statement, Yusuf (2013) mentioned that giving the student the experience of understanding deeper cognitive skill with social affective in teaching learning process increased the intelligence and skill in processing the information to the students. In line with that, Sanjaya (2006) claimed that students who got those experience show greater contribution in teaching learning process rather than the students who did not get the experience.

Few researches conducted teaching vocabulary with word map strategy. They claimed that the strategy was effective in developing vocabulary for English learners (Abdel Rahman, 2013; Utami, 2016). Therefore, there is none of the study in applying word map strategy with technology as supporting medium that now has mushroomed in teaching learning process.

Technological advancing progress have opened a whole new world of opportunities for foreign language learners to interact and engage with many sources and methods. There has been a spiking interest in researching informal foreign language learning using new digital media that can be accessed online, such as blogs, music, 
and videos series (e.g., Sockett, 2014; Sockett \& Toffoli, 2012; Toffoli \& Sockett, 2010; Alhamami, 2014). Dunan (2011) said that since mid 1600-s the massive usage of technology in many fields has also give rise to education domain advancement. However, the exponential growth of technology in each era has different effect and usage on teaching learning process system. Social media is one of the emerging technology that has gratified people's life which ease the people to communicate without any meaningful restraint. One of the most wellknown social media is Instagram (Knight-McCord et al., 2016) which offer the user to capture their moment life through a series of pictures or videos and post them on their own account $(\mathrm{Hu}, 2014)$. Their follower could freely give feedback by giving like or comment to the user's post. Since Instagram's content primary language is English, it is easy to find videos and materials supporting teaching English in many occasions and subjects (Qisthi \& Arifani, 2020).

In additional, using technology in teaching learning process can optimize the managing of time schedule that sometimes become main problem in the teaching and learning process. By using technology, students can do self-learning to develop their vocabulary (Maruf \& Anjeli, 2020). In reporting, the students can report the progress to their teachers by showing their historical search, following accounts, commenting and tracking records.

From those issues, the researcher is interested to conduct this study to use word map method combined with social media, such as Instagram to get to know the significant different in teaching vocabulary. The application of this combination is also improve the individualist and collaborative students self-learning because it can be worked in both strategies. Moreover, the researcher eagers to prove that the combination can fulfill the need of thinking critical and analytical in teaching vocabulary and shares creativity that can be applied in teaching EFL classroom.

\section{METHOD}

\section{a. Research Design}

This research was used in an experimental design by using quantitative approach. The purpose of experimental study is to determine if a specific treatment influences an outcome. The researcher did this study by presenting a specific treatment to one group and withholding it from another and then analyzing how both groups scored on an outcome (Ary, 2006 as cited in Fitri, 2020).

The researcher used quasi experimental design to measure the data score of the participants in pre and posttest, which it is non-randomized sample for pre-test and post-test. It was done to find out whether there is significant effect of word map strategy using Instagram to develop students' vocabulary. The design chart can be seen in figure below:

Table 1. Non-Randomized Subjects, pre-test and post-test quasi experiment design.

\begin{tabular}{|l|l|l|l|}
\hline Group & Pre-test & Treatment & Post-test \\
\hline Experiment & Y1 & $\mathrm{X}$ & Y2 \\
\hline Control & Y1 & - & Y2 \\
\hline
\end{tabular}

Y1 : The pre-test which is administered before the treatment

$\mathrm{X}$ : The treatment

Y2 : The post-test which is administered after the treatment 


\section{b. Procedures}

The research procedures in this study can be implied as illustrate in figure below

\section{c. Participants}

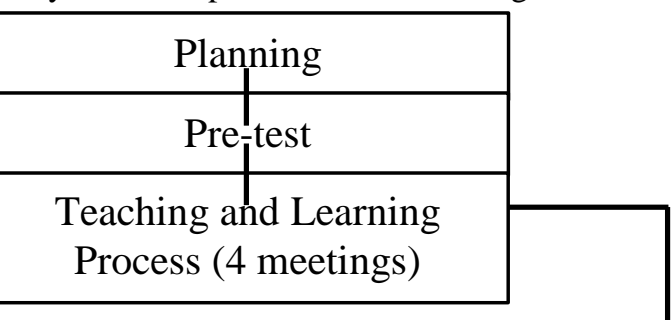

Treatment Group

a. The participant was class $8 \mathrm{~F}$, consists of 33 students.

b. The class was divided into 6 groups with 5 until 6 members.

c. The class was treated with word map strategy and used Instagram as the main source of teaching learning process.

The participants of this research were eight grade students at SMP Islam Manbaul Ulum Gresik in the academic year of 2019-2020. There were six classes with 192 students in total. The researcher gave all the classes pre-test in order to know which classes has the same homogeneity. The researcher analyzed mean score of pretest score of each classes and decided which classes would be participated. After analyzing, the researcher took two classes as the participants of the research. They were class of $8 \mathrm{E}$ with 31 students and another class of $8 \mathrm{~F}$ with 33 students. $8 \mathrm{E}$ was representative of control group while $8 \mathrm{~F}$ for treatment/experimental group. The research was conducted in January to February 2020. The data of the research was divided into two terms. They were the teaching learning process research data in January 2020, and the questionnaire data was taken in February 2020.

\section{d. Instruments}

In this research, the researcher used test as instrument to collect the data and questionnaire to support the data analysis. Both of the group experienced pre and post test to measure the vocabulary master. Therefore pre-test was also administrated to all eighth grade classes to know the homogeneity among six classes in the school. The questionnaire was then given to treatment group to answer the second statement of the problem in this research after the treatment group did the post test.

In this research, the researcher used vocabulary level test. It was originally developed by Nation (1983) and then updated by Schmitt. In order to determine the development, Schmitt and Clapham (2001) used vocabulary level test to the test takers to know the form-meaning connections of words. The test had been validated by Webb, Sasao and Balance in 2017. This test was consisted of 30 questions each level with the same proportion of noun, verb and adjective. It was applied to know at how well students comprehended English words by matching the main question word to the multiple choice answers.

A set of questionnaires with 14 closed-ended items are distributed to treatment group, consists of 33 students after having treatment. The questionnaire is adapted based on two existing studies by Elsayyed Sanad (2016) and Yuni akhiar et al. (2017), who had examined the suitability of social media, Facebook and Instagram as an educational learning tool. The adapted items were tested for its reliability using the Cronbach's Alpha Test to investigate the internal consistency of the question items within the questionnaire. A set of questionnaires with 
14 closed-ended items are distributed to treatment group, consists of 33 students after having treatment. The questionnaire is adapted based on two existing studies by Elsayyed Sanad (2016) and Yuni akhiar et al. (2017), who had examined the suitability of social media, Facebook and Instagram as an educational learning tool. The adapted items were tested for its reliability using the Cronbach's Alpha Test to investigate the internal consistency of the question items within the questionnaire.

\section{e. Data Analysis}

After the data was collected, then it follow by data analyzing. It was conducted to be able to interpret the data which obtained from the test. Data analysis was aimed to answer the research problem which the data presented from pre-test and post-test. SPSS version 17.0 was used by the researcher to compute descriptive statistic.

Assumptions for the independent t-test were: (1) Independence: Observations within each sample had to be independent (they did not influence each other). (2) Normal distribution: The scores in each population had to be normally distributed. (3) Homogeneity of variance: The two populations should have equal variances (the degree to which the distributions were spread out was approximately equal).In this study the researcher did not need normality distribution because the sample of this study was not from random population, so this study just needed homogeneity to know the samples were homogeneous or not.

the data from questionnaire analyzed by using percentage, the researcher applied the formula as follows:

$$
\mathrm{P}=\frac{\mathrm{Fq} \times 100 \%}{\mathrm{~N}}
$$

In which:

$\mathrm{P}=$ Percentage

$\mathrm{F}=$ Frequency of Item

$\mathrm{N}=$ Total Sample (Sugiyono, 2014: 45).

To rate the frequency and percentage of students' perception toward the usage of Instagram in developing vocabulary the researcher uses criteria:

a. $76-100=$ Very High

b. $56-75=$ High

c. $26-55=$ Low

d. $0-25$ = Very Low (Sugiyono, $2014: 20)$

\section{RESULTS AND DISCUSSION}

\section{Results}

In this research, the researcher used test as instrument to collect the data and questionnaire to support the data analysis. Both of the group experienced pre and post test to measure the vocabulary master. Therefore pre-test was also administrated to all eighth grade classes to know the homogeneity among six classes in the school. The questionnaire was then given to treatment group to answer the second statement of the problem in this research after the treatment group did the post test.

Table 2. Group Equivalence on Baseline Score

\begin{tabular}{lllllll}
\hline Group & $\mathbf{N}$ & Mean & S.D. & df & $\boldsymbol{t}$ & $\boldsymbol{p}$ \\
\hline Treatment & 33 & 12.91 & 5.141 & \multirow{2}{*}{62} & \multirow{2}{*}{$t=-1.508$} & 0.137 \\
Control & 31 & 10.81 & 5.950 & & & \\
\hline
\end{tabular}

In which:

$d f=$ degree of freedom

$\mathrm{SD}=$ standard deviation 
Table 3. Means and Standard Deviation (SD) of Vocabulary Test Scores by Groups Prepost Treatment.

\begin{tabular}{lllll} 
Group & Condition & N & Mean & SD \\
\hline Control & Pre & 31 & 10.81 & 5.141 \\
& Post & 31 & 12.00 & 4.382 \\
\hline Treatment & Pre & 33 & 12.91 & 5.950 \\
& Post & 33 & 15.36 & 6.015 \\
\hline
\end{tabular}

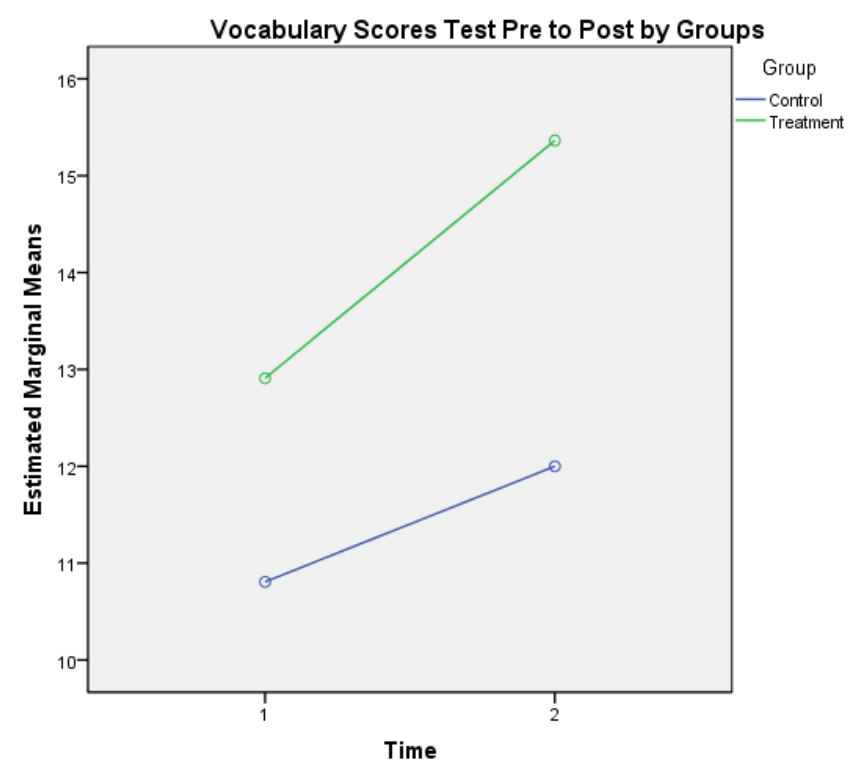

Figure 1. Vocabulary Score Improvement from Pre to Post by Group

Table 3 provided means and standard deviation of pre and post test for both groups. Result from twoway mixed ANOVA revealed a significant time effect for the two groups, $F(1,62)=26.430, p<0.001$. However, no significant interaction time x group was found $F(1,62)=3.158, p=0.08$. Further analysis using paired-sample $t$-test show development vocabulary in the treatment group, $t(32)=-5.40, p<0.001$ as well as in the control group, $\mathrm{t}(30)=-2.712, p=0.038$.

As a seen in the figure 1, this indicated both group performed better on their vocabulary scores at posttest. Nonetheless the treatment group show a $18.98 \%$ improvement compared to a $11 \%$ improvement for the control group, with the mean score of post-test control group was 12.00 correlated to post test of treatment group was 15.36. Figure 1 also displayed pre-post vocabulary scores by group. It also presented that the researcher concluded that students in the treatment group achieved better development on vocabulary test than the control group.

The descriptive statistics of questionnaire responses by 33 participants in the treatment group. In general, for each question, the students reported agree about the use of Instagram that had positive influence in learning English as foreign language. Moreover, the students claimed that Instagram could help the students in developing their vocabulary. They easily found new vocabulary as they observed through English account on Instagram and hashtag to aid them discovered new vocabulary. In addition, the combination between Instagram and word map prompted significant effect in gaining their vocabulary.

The researcher concluded that the majority of the students in the treatment group had positive interest in learning and developing vocabulary through word map strategy and Instagram. The combination of the strategy and the tool presented by the researcher experienced the students to explore the vocabulary easily. Ramadhani in her thesis in 2017 also mentioned that Instagram facilitated the student high motivation and show 
great effect in learning vocabulary through Instagram.

Regarding to the average of the students' perception towards word map strategy and Instagram in learning vocabulary, the researcher had calculated it by using Gay's theory, where total score of questionnaire was divided with the total number of sample. If "strongly agree" was valued 5 and "strongly disagree" was valued 1, the result of the questionnaire mean was 3.69. It indicated that the students in the treatment group agreed that Instagram helped them in developing vocabulary with word map strategy.

\section{Discussion}

Instagram provided the students vocabulary library source, the richness of students in treatment group was better than the students in control group. Each students in treatment group had different way in gaining vocabulary through Instagram, they also followed different English account and searched new vocabulary from different hashtag so that they got different unfamiliar words too. When it was brought into the classroom, they exchanged their knowledge and made some discussions about the words. As a result, they got many new words from their own and from their peers. So when the students did word map strategy the students could build better relationship in linking word to other words in word map strategy. Laponsie in 2013 about the way Instagram helped the teacher in teaching learning process said that Instagram integrated into classroom activity could provide good medium for students to connect and engage with the lesson concept. The students would experience better knowledge by blending the Instagram with the classroom activity. Tan, Ladyshewsky \& Gardner (2010) claimed that the students' work, attitude, and feedback indicated that blended learning show creative learning and helped the students completed their creative works. They were able to interact, communicate, reflect, and learn from each other in a harmonic, supportive and peer assisted learning environment.

Furthermore, Instagram became fun learning English learning tool. The students show positive attitude towards Instagram. The researcher found that Instagram facilitated dynamic communication inside and outside the classroom. This strategy increased the student self-efficacy because they were confidence to study in their own and they were willing to share their knowledge among others. The blended learning made the students were able to pay attention, organize, and elaborate material effectively in teaching learning process (Zajacova, Scott, Lynch, \& Espenshade, 2005; Heslin, \& Klehe, 2006).

The class discussion about Instagram finding provided by the researcher also created a sense of community and belonging, it build the students' social aspect too. Even more, when the researcher blended it with word map strategy the students established the social communication through some discussion and analysis. This study is supported by Palerangi et al., (2017) that there was positive impact through cooperation in group discussion. The students in the group motivated each other, exchanged ideas, concluded same perception and develop their social interaction well.

To sum up the description above, it was revealed that the students' vocabulary mastery developed significantly after each classes received a four-time treatments by word map strategy. It was indicated by the mean score of posttest which was higher than the mean score of pretest. The increase of the mean declared that word map strategy had good impact on the students' vocabulary mastery. However the use of Instagram in the treatment group show higher output than in control group. The data analysis show that the difference mean score of both group was 2.45 point higher. As a result, the combination of word map strategy and Instagram was more effective to develop students' vocabulary.

\section{CONCLUSION}

Two statements of the problem became main focus in this research. Based on the finding and discussion about the effect of word map strategy using Instagram to develop students vocabulary in the previous chapter, the researcher drew conclusion that word map strategy had significantly effect in promoting students vocabulary on eight grade of SMP Islam Manbaul Ulum Gresik academic year of 2019/2020. It was proven by the data of the mean score that both of the control and treatment group show the development from the pre and posttest.

Therefore there was difference in increasing score of both groups. The control group reached $11 \%$ from pretest to posttest after having word map strategy without Instagram as the integration tool, while the treatment group increased into $18.98 \%$ after experiencing word map strategy and Instagram as learning tool to improve students' vocabulary. Instagram was considered able to aid the students developing their mastery in vocabulary. It was supported by the overall mean score of the questionnaire. The mean score was 3.69 point. It indicated that the students agreed that Instagram became positive combination tool with word map strategy in learning vocabulary. The researcher also found that Instagram provided good source and reference to add new 
vocabularies and get their meanings more easily than the students who did not get word map strategy and Instagram in the research

\section{REFERENCES}

Abdel rahman, Omar. (2013). The Effect of Teaching Vocabulary through Semantic Mapping on EFL Learners. Arab Saudi: Al Imam Mohammed Ibin Saud Islamic University.

Ahour, T., \& Berenji, S. (2015). A Comparative Study of Rehearsal and Loci Methods in Learning Vocabulary in EFL Context. Theory and Practice in Language Studies, 5(7), 1451-1457

Akhyar et.al. (2017). Students' Perceptions and Attitudes towards the Use of Instagram in English Language Writing. Malaysian Journal of Learning and Instruction (MJLI), Special issue on Graduate Students Research on Education, 47-72.

Alizadeh, I., \& Branch, L. (2016). Vocabulary Teaching Techniques: A Review of Common Practices. International Journal of Research in English Education. 1(1), 22-30.

Ary, D.; Jacobs, L. C.; Sorensen, C. \& Razavieh, A. 2006. Introduction to Research in Education (8th ed.). Belmont, CA: Wadsworth, Cencage Learning.

Duman, A., \& Orhon, G. (2014). The Effect of Visually-Supported Vocabulary Instruction on Beginner Efllearners' Vocabulary Gain. MEXTESOL Journal, 37(1), 1-12.

Elsayyed Sanad, H. A. (2016). EFL Students' Perceptions and Attitudes towards Facebook as an Educational learning tool. International Journal of Humanities and Social Science Invention ISSN (Online): 2319 7722, ISSN (Print): 2319 - 7714, 5 (9), 15-25.

Fitri, I. D. (2020). Revitalizing the Roles of EFL Teacher Forum for Developing Teachers Professionalism. The Borneo International Conference on Education and Social Sciences (BICESS 2018), p.307-316. SCITEPRESS - Science and Technology Publication, Lda. https://doi.org/10.5220/0009020403070316.

$\mathrm{Hu}$, Yuheng et.al. (2014). What We Instagram: A First Analysis of Instagram Photo Content and User Types.

Kafadar, T. dan Tay. B. (2014). Learning Strategies and Learning Style Used by Student in Social Studies. International Journal of Academic Research. Vol. 2(2):259- 264.

Knight-McCord et.al. (2016). What Social Media Sites Do College Students Use Most? Journal of Undergraduate Ethnic Minority Psychology Spring; 21.

Maruf, N. \& Anjeli, M. R. (2020). Utilizing Cooperative Integrated Reading and Composition (CIRC) with Mobile Learning to Enhance Students' Reading Comprehension. British (Jurnal Bahasa dan Sastra Inggris) 9(2), 10-19. https://doi.org/10.31314/british.9.2\%25p.2020.

Medina, L. C. (2018). Blended learning: Deficits and Prospects in Higher Education. Australasians Journal of Educational Technology, 34(1), 42-56.

Melieta, L. H. H. (2016). "The Use of Word Mapping Technique in Teaching Vocabulary". Thesis. Universitas Negeri Pontianak.

Moghaddam, M. P., \& Mazaheri, S. (2017). The Effect of Pedagogical English Smartphone Applications on Iranian Intermediate ESL Learners' Active Vocabulary. Modern Journal of Language Teaching Methods, 7(1), 47-54.

Nation, I. S. P. (2001). Learning Vocabulary in Another Language. Cambridge: Cambridge University Press.

Nation, I. S. P. (2008). Teaching Vocabulary: Strategies and Techniques. Boston, MA: Heinle Cengage Learning.

Nur, R., Ammang, L., \& Aqilah, L., B. (2019). Utilizing the Instagram Videos to Enhance the Students' Language Acquisition on Writing Composition. Asian EFL Journal Research Articles, Vol. 23 Issue No. 
O’Malley, J. M and Chamot, A.U. (1995). Learning Strategies in Second Language Acquisition. Cambridge Applied Linguistic.

Palerangi, Tuwoao dan Andoko, 2016. Kontribusi Kemandirian Belajar dan Keterampilan Sosial Terhadap Kompetensi Kejuruan Siswa Paket Keahlian Teknik. Jurnal Pendidikan Teori dan Pengembangan, 1 (9):1806-1816.

Qisthi. N, \& Arifani, Y. (2020). The Application of Project Based Learning via Instalgram to Improve EFL Students' Speaking Skill. In The Borneo International Conference on Education and Social Sciences (BICESS 2018), p.201-209. SCITEPRESS - Science and Technology Publication, Lda. https://doi.org/10.5220/0009018802010209.

Sanjaya, W. (2006). Strategi Pembelajaran Berorientasi Standar Proses Pendidikan. Jakarta: Prenamedia Group. Schmitt, N. (1997). Vocabulary Learning Strategies. In Schmitt, N. and McCarthy, M. (eds.), Vocabulary: Description, Acquisition, and Pedagogy. Cambridge: Cambridge UniversityPress

Schmitt, N. (2000). Vocabulary in Language Teaching. Cambridge: Cambridge University Press.

Sharples, M. (2006). Big Issues in Mobile Learning. Report of a Workshop by the Kaleidoscope Network of Excellence Mobile Learning Initiative. University of Nottingham, UK.

Smith Jr., E. V. (2004). Evidence for the Reliability of Measures and Validity of Measure Interpretation: a Rasch Measurement Perspective. In E. V. Smith Jr. \& R. M. Smith (Eds.), Introduction to Rasch measurement: Theory, Models and Applications (pp. 93-122). Maple Grove, MN: JAM Press.

Sockett, G., \& Toffoli, D. (2012). Beyond Learner Autonomy: A Dynamic Systems View of the Informal Learning of English in Virtual Online Communities. Procedia - Social and Behavioral Sciences, 34, 212 215.

Tan, S. M., Ladyshewsky, R. K. \& Gardner, P. (2010). Using Blogging to Promote Clinical Reasoning and Metacognition in Undergraduate Physiotherapy Fieldwork Programs. Australasian Journal of Educational Technology, 26(3), 355-368.

Yusuf, S, L.N dan Sugandhi, N.M. 2013. Perkembangan Peserta Didik. Jakarta: Raja Grafindo Persada.

Zajacova, A., Scott, M., Lynch, S. M., \& Espenshade, T. J. (2005). Self-Efficacy, Stress and Academic Success in College. Research in Higher Education, 46(6), 132-143. 